\title{
KIER, Hiltrud, GECHTER, Marianne, Frauenklöster im Rheinland und in Westphalen
}

\section{Michèle Gaillard}

\section{OpenEdition}

\section{Journals}

Édition électronique

URL : http://journals.openedition.org/ifha/816

DOI : 10.4000/ifha.816

ISSN : 2198-8943

Éditeur

IFRA - Institut franco-allemand (sciences historiques et sociales)

Référence électronique

Michèle Gaillard, « KIER, Hiltrud, GECHTER, Marianne, Frauenklöster im Rheinland und in Westphalen », Revue de l'IFHA [En ligne], Date de recension, mis en ligne le 01 janvier 2005, consulté le 22 septembre 2020. URL : http://journals.openedition.org/ifha/816 ; DOI : https://doi.org/10.4000/ifha.816

Ce document a été généré automatiquement le 22 septembre 2020

(CIFHA 


\title{
KIER, Hiltrud, GECHTER, Marianne, Frauenklöster im Rheinland und in Westphalen
}

\author{
Michèle Gaillard
}

Ce petit ouvrage, préparé dans le sillage des expositions Krone und Schleier d'Essen et de Bonn, se présente sous la forme d'un guide touristique des communautés religieuses de femmes en Rhénanie et Westphalie, depuis Minden au nord jusqu'à Mayence et Trèves au sud, avec une échappée aux Pays-Bas (Susteren). Il offre 13 itinéraires de découvertes avec des cartes très lisibles et utilisables en voiture. L'ensemble est précédé d'une introduction claire et précise sur l'histoire de la vie religieuse féminine et d'une petite bibliographie. Pour chaque établissement sont donnés l'ordre (ou les ordres) religieux d'appartenance, la nature des vestiges existants, un court résumé historique et un court commentaire sur l'architecture, suivis le cas échéant de paragraphes sur la décoration de l'édifice, sur l'importance de l'établissement dans la vie de l'ordre ou dans la vie religieuse, sur les environs ; le tout est invariablement clôturé par une courte bibliographie et des informations pratiques sur le site. Chaque notice est pourvue de deux photographies d'excellente qualité et d'un encadré sur un mot-clé révélateur du passé ou de l'intérêt de l'édifice (personnage, objet, élément d'architecture...). Pourvu d'un lexique et d'un index, cet ouvrage réussit donc parfaitement la synthèse entre le guide touristique et le manuel érudit ; il sera sans aucun doute très utile à ceux qui prendront le temps de flâner à la découverte des communautés religieuses d'autrefois et sera d'une consultation très agréable pour ceux qui rêvent d'en avoir le temps.

Michèle GAILLARD (Université Paul-Verlaine, Metz) 